\title{
Summer Habitat Use by Littoral-Zone Fishes in Lake Tahoe and the Effects of Shoreline Structures
}

\author{
David A. BEAUChamp \\ Cooperative Fisheries and Wildlife Research Unit ${ }^{1}$ \\ Department of Fisheries and Wildlife/Ecology Center, Utah State University \\ Logan, Utah 84322-5210, USA \\ EARL R. BYRON ${ }^{2}$ \\ Division of Environmental Studies, University of California \\ Davis, California 95616, USA \\ WAYNE A. WurTSBAUGH \\ Department of Fisheries and Wildlife/Ecology Center \\ Utah State University, Logan, Utah 84322-5255, USA
}

\begin{abstract}
We used scuba observations to determine summer habitat use and the effects of piers on the littoral-zone fish community in Lake Tahoe, California-Nevada. Habitat complexity declined with depth. Over $50 \%$ of the littoral zone less than $2 \mathrm{~m}$ deep was composed of complex boulder substrates, but this substrate represented less than $10 \%$ of the habitat between 10 and 18 $\mathrm{m}$ deep. A severe drought lowered the surface elevation of the lake $2 \mathrm{~m}$ and reduced the wetted complex rocky habitat by $20 \%$ between the $0-$ and $10-\mathrm{m}$ isobaths (referenced to the mean lake level of 1,899 m above sea level). The dominant littoral-zone fish, adult Lahontan redsides Richardsonius egregius, were found at depths ranging from $1-10 \mathrm{~m}$ over substrates, but at somewhat greater depths (3-10 m) over cobble-boulder substrates. Juvenile Lahontan redsides were concentrated around boulders at depths of 1-3 m, and their densities were much lower than the densities of adults. Adult tui chub Gila bicolor and rainbow trout Oncorhynchus mykiss were also most often associated with complex boulder habitats. The daytime densities and species composition of fishes associated with piling-supported piers did not differ significantly from adjacent no-pier areas, whereas the densities of Lahontan redsides, tui chubs, Lahontan speckled dace Rhynichthys osculus robustus, and Tahoe suckers Catostomus tahoensis associated with the complex structure of rockcrib piers were significantly higher than in adjacent no-crib areas. Fish density increased 5-12-fold at night relative to the observed daytime densities in the pier, rock-crib, no-pier, and no-crib transects.
\end{abstract}

The littoral zones of lakes are an important habitat for some or all life history stages of many fishes. Numerous fish species concentrate in or around nearshore cover (e.g., Wurtsbaugh et al. 1975; Hall and Werner 1977). Habitat complexity provides refuge from predators (Mittlebach 1981, 1984; Savino and Stein 1982; Werner et al. 1983a; Gotceitas and Colgan 1987; Johnson et al. 1988; Lynch and Johnson 1989; Tabor and Wurtsbaugh 1991) or profitable foraging areas (Mittlebach 1981, 1984; Werner et al. 1983b). In most of the studies cited, aquatic macrophytes provided the physical

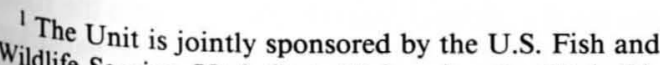
Wildlife Service, Utah State University, the Utah Division of Wildlife Resources, and the Wildlife Management Institute.

${ }^{2}$ Present address: $\mathrm{CH}_{2} \mathrm{M}$ Hill, 2485 Natomas Park

Drive, Suite 600 , Sacramento, California 95833, USA. structure used by nearshore fish communities; less is known about the role of rocky habitat in structuring nearshore fish communities, particularly in mountain lakes. The purposes of our study were to (1) assess the availability of natural substrate types in Lake Tahoe, (2) describe the relationship between fish populations and littoral habitat by depth, and (3) examine the effect of shore-zone structures on the densities of littoral-zone fishes.

As demand for commercial and recreational development of lake shorelines continues to increase, knowledge of the effects of littoral-zone alteration on habitat use by the fish community assumes greater importance. Lake Tahoe, California-Nevada, is an excellent study area for examining the effects of shore-zone structures and habitat alterations on fish populations. Over the last 30 years there has been a 10 -fold increase in human population within the basin and a concomitant increase in shoreline development (Goldman 1988). 
The most common anthropogenic alterations of the physical structure of the littoral zone have been the construction of piling-supported piers (hereafter termed piers) and rock-crib piers (hereafter termed cribs) and the redistribution of cobbles (64$256 \mathrm{~mm}$ diameter) and boulders ( $>256 \mathrm{~mm} \mathrm{di-}$ ameter) in the shallow (O-2 m) littoral zone. A recent drought (1987-1992) reduced the mean lakesurface elevation from $1,899 \mathrm{~m}$ to $1,896 \mathrm{~m}$ above sea level and altered shore-zone habitat by reducing the amount of submerged rocky substrate around the lakeshore. Since 1900, the surface elevation of Lake Tahoe has fallen below the natural rim $(1,896.8 \mathrm{~m}$ above sea level) in 1925,1930 1936, 1962, 1978, 1978, 1989, and 1991-1992. The extent to which these changes are detrimental to fish communities concerns both regional planners and fishery managers.

In this paper, we first present a lake-wide inventory of the bottom substrates currently present in the littoral zone (bottom depths $<18 \mathrm{~m}$ ) of Lake Tahoe. We then examine relationships between substrate type, depth, and summertime fish density in unaltered habitats. Finally, we examine the effects of the two common shoreline structures, piers and cribs, on the density of littoral-zone fishes.

\section{Study Area}

Lake Tahoe is a large $\left(500 \mathrm{~km}^{2}\right.$ surface area), deep (505 m maximum depth, 313 m mean depth), ultra-oligotrophic (chlorophyll $a<0.5 \mathrm{mg} / \mathrm{m}^{3}$, Secchi-depth transparency normally $>25 \mathrm{~m}$ ), subalpine lake located just east of the crest of the central Sierra Nevada between California and Nevada (Goldman 1988). A 3-m-high dam at the outlet increases the depth over the natural sill during wet years. In Lake Tahoe, macrophytes are rare in water less than $10 \mathrm{~m}$ deep, but beds of Chara delicatula are found in water $6-110 \mathrm{~m}$ (Frantz and Cordone 1967). Nevertheless, for this study, we refer to nearshore waters between 0 and $18 \mathrm{~m}$ as the "littoral zone" since these depths encompass the greatest change in substrate and bracket the summer depth range of the predominant native fishes. The substrates of the littoral zone are mixtures of sand, gravel, cobble, and boulder above the $10-\mathrm{m}$ isobath, but at deeper levels it is predominantly sand, clay, and silt (Frantz and Cordone 1967; Beauchamp et al. 1992).

The littoral fish community consists of minnows, suckers, sculpins, and salmonids (Miller 1951). The predominant littoral species are native fishes, primarily Lahontan redsides Richardsonius egregius (Evans 1969), Lahontan speckled dace Rhynichthys osculus robustus (Baker 1967), intergeneric hybrids between these cyprinids and tui chubs Gila bicolor (Hopkirk and Behnke 1966), and the native Tahoe sucker Catostomus tahoen. sis. Tui chubs and Piute sculpin Cottus beldingi are also present in the littoral zone, but in lower numbers. Most of the native minnows, particularly Lahontan redsides, concentrate in the upper $10 \mathrm{~m}$ of the littoral zone during the summer (Evans 1969), but move down-slope to a modal depth of $20 \mathrm{~m}$ from October to mid-June. These minnows represent the bulk of the fish biomass in the lake (Tahoe Research Group, unpublished data). Mountain whitefish Prosopium williamsoni, rainbow trout Oncorhynchus mykiss, and brown trout Salmo trutta are the sport fishes that commonly inhabit the littoral zone; lake trout Salvelinus namaycush and kokanee Oncorhynchus nerka (lacustrine sockeye salmon) are occasionally found in littoral areas during periods of thermal destratification. Lahontan redsides, tui chubs, and signal crayfish Pacifasticus leniusculus represent the primary prey of brown trout and rainbow trout. In addition to these species, Piute sculpin, kokanees, and Tahoe suckers are seasonally important prey of lake trout. Therefore, the productivity of the sport fish populations is directly linked to habitat use and availability of the native littoral fishes.

\section{Methods}

\section{Characterization of Littoral Substrate}

The substrate characteristics of the littoral zone were mapped, based on observations taken on June 13,14 , and 23,1988 , when lake-surface elevation was $1,897.2 \mathrm{~m}$. Windless, clear skies and the exceptional water transparency (Secchi depth $>25$ m) provided excellent conditions for visual assessment of the substrate. We mapped the substrate from the flying bridge of a $12-\mathrm{m}$ boat, cruising parallel to shore at $6 \mathrm{~km} / \mathrm{h}$ over a mean bottom depth of $8 \mathrm{~m}$. The $8-\mathrm{m}$ isobath was selected because (1) it was a safe depth close to shore, (2) preliminary observations indicated that the most dramatic change in substrate composition occurred at or above this depth, (3) the modal density of littoral fishes occurred at or above this depth during the summer, and (4) it represented the 10-m isobath under normal lake levels. The substrate survey was divided into seven areas corresponding to the statistical reporting areas used by the $\mathrm{Cal}$ ifornia Department of Fish and Game and the Nevada Department of Wildlife for reporting sport 
TABLE 1.-Size classification, following Lane (1947), of substrates found during the littoral zone survey of Lake Tahoe.

\begin{tabular}{lc}
\hline \multicolumn{1}{c}{ Substrate } & Size range $(\mathrm{mm})$ \\
\hline Sand & $<2$ \\
Gravel & $2-64$ \\
Cobble & $>64-256$ \\
Boulders & $>256$ \\
Bedrock and Clay & \\
\hline
\end{tabular}

fish catches. We inventoried the substrate of three separate zones: (1) the dry shoreline exposed by the extremely low water level of the lake, (2) the submerged nearshore area between shore and the boat $(0-8 \mathrm{~m})$, and (3) the area lakeward of the boat to a depth of approximately $18 \mathrm{~m}$. Each area was characterized by the percentage composition of each of five substrate classes, roughly following the American Geophysical Union nomenclature (Lane 1947), plus a category for bedrock and clay (Table 1). Within each 2-min cruising interval (corresponding to 200 lineal meters of shoreline), we recorded latitude and longitude (to the nearest 0.01 minute; Loran C), and depth (to the nearest $0.1 \mathrm{~m}$ with an echo sounder). We visually estimated the percentage of each substrate in each depth zone within each $200 \mathrm{~m}$ observation area and counted the number of piers, cribs, floating docks, and buoys. The survey thus represented a continuous assessment of the entire lakeshore. The potential error from visual estimates of substrate composition was not measured directly, but was assumed to be about $\pm 5-10 \%$. Because major differences in substrate composition occurred on a scale of 10-100 lineal meters, estimates of proportional substrate composition were manageable within 200-m observation intervals. In all, 586 of these 2-min observations were recorded around the $114-\mathrm{km}$ perimeter of the lake. The $3 \%$ discrepancy between $586 \times 200 \mathrm{~m}=117.2 \mathrm{~km}$ and the actual $114 \mathrm{~km}$ shoreline was the result of cumulative slight deviations in boat speed and in the timing of the observation intervals. The changes in percentages of individual substrate categories among areas was analyzed with the Kruskal-Wallis nonparametric analysis of variance (ANOVA).

\section{Substrate-Specific Fish Density Observations}

Fish densities were estimated along underwater transects at 47 sites around the lake in daylight during the summers of 1988 and 1989 (Figure 1). In 1988, scuba divers surveyed 1-m- and 3-mdeep preliminary transects at 17 sites, then $1-\mathrm{m}-$ -

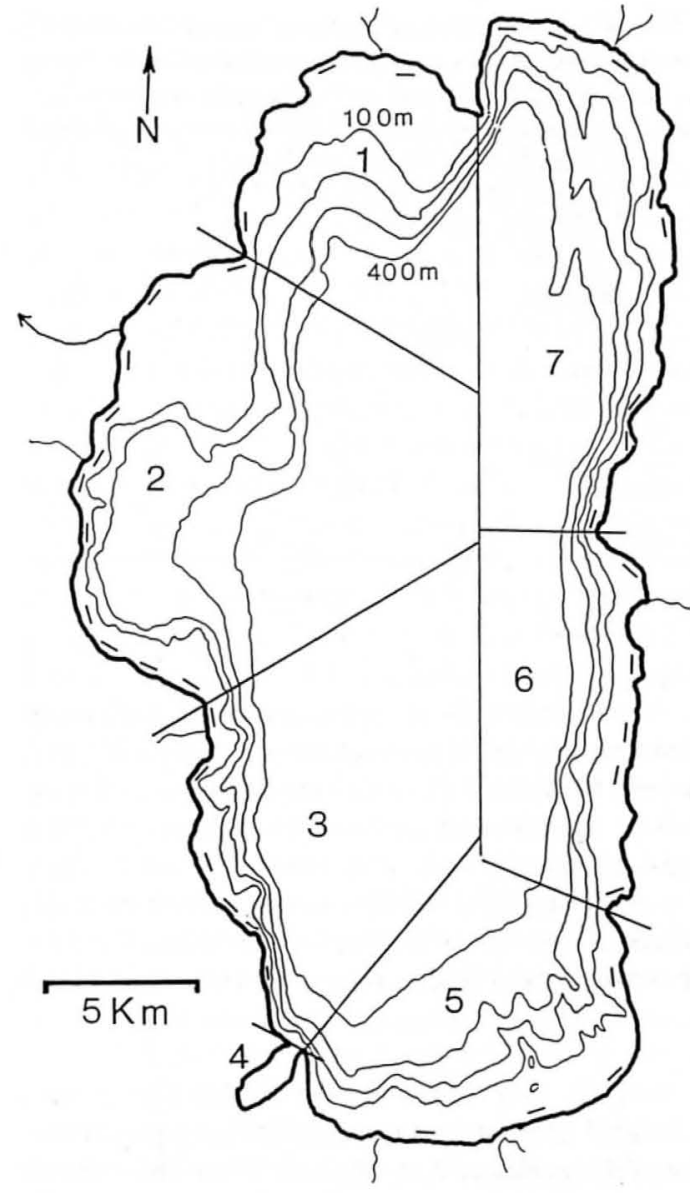

FIGURE 1.-Morphometric map of Lake Tahoe showing the numbered reporting areas used in littoral zone substrate mapping. The locations of scuba transects used to relate fish density to depth and substrate are indicated by short lines near shore.

3-m-, and 10-m-deep transects at each of 13 additional sites. The 10-m-deep transects were included to bracket the observed summer depth distribution of the predominant Lahontan redsides. In 1989,17 additional sites were surveyed at depths of $1,3,10$, and $20 \mathrm{~m}$. The $20-\mathrm{m}$ transect depths were added in 1989 to provide comparable data from depths below our definition of a functional littoral zone and because $20 \mathrm{~m}$ was the depth of modal minnow densities during the winter (Beauchamp et al. 1991). The survey sites were selected in a stratified random design based on information from the littoral substrate assessment described above; samples were allocated among substrate types in proportion to the expected variability of fish densities within habitat types, based on den- 
TABLE 2.-Numbers of scuba transects surveyed by depth and substrate combination in Lake Tahoe during the summers of 1988 and 1989. Sample sizes were unequal among depth-substrate cells because rocky habitat declined rapidly with depth (see Figures 2 and 3). The 20-m transects were surveyed in 1989 only.

\begin{tabular}{lrrrr}
\hline \multirow{2}{*}{\multicolumn{1}{c}{ Substrate }} & \multicolumn{4}{c}{ Depth (m) } \\
\cline { 2 - 5 } & \multicolumn{1}{c}{1} & 3 & 10 & 20 \\
\hline Sand & 4 & 11 & 21 & 10 \\
Sand-cobble & 10 & 3 & 0 & 0 \\
Sand-boulder & 5 & 7 & 2 & 1 \\
Cobble & 11 & 10 & 0 & 1 \\
Cobble-boulder & 3 & 9 & 3 & 2 \\
Boulder & 14 & 7 & 4 & 3 \\
Total transects by depth & 47 & 47 & 30 & 17 \\
\hline
\end{tabular}

sities observed in the first 17 transects at 1 and 3 $\mathrm{m}$. We consistently encountered combinations of substrates when selecting the fish transects; consequently, we used the following classification: sand (100\% sand); sand-cobble (10-30\% cobble, 70 $90 \%$ sand); cobble (100\% cobble); sand-boulder (10-30\% boulder, $70-90 \%$ sand); cobble-boulder (30-70\% cobble, $30-70 \%$ boulder); and boulder (100\% boulder). The number of transects surveyed in each depth-habitat combination is shown in Table 2.

At each site, scuba divers swam 100-m-long transects $1 \mathrm{~m}$ above the bottom and parallel to shore at depths of $1,3,10$, and $20 \mathrm{~m}$. Prior to the 1988 fish transect series, we timed divers swimming premarked 100 -m-long by $4-\mathrm{m}$-wide transects in a variety of habitat types ranging from $100 \%$ sand to $100 \%$ boulder substrates. The mean time to swim a transect was $10.2 \pm 0.6$ min (mean $\pm 2 \mathrm{SE}$ ); therefore, all subsequent transects were swum for $10 \mathrm{~min}$ for an assumed $100-\mathrm{m}$ length. Divers were conditioned during the 18 presurvey transects to recognize a 2-m swath on each side of the transect path, so subsequent dives were not premarked. During each transect, the diver recorded data on a preformatted slate, including the substrate type, the slope, and the number, species, and size-class of all fishes observed on the bottom or in the water column. The size-classes of fishes discriminated between yearlings (total length $\leq 40$ $\mathrm{mm}$ for cyprinids and Piute sculpin, $\leq 100 \mathrm{~mm}$ for Tahoe suckers, and $\leq 150 \mathrm{~mm}$ for salmonids) and adults. Larval native fishes generally resided in the shallow margins (1-15 cm deep) of the lake and were not included in the surveys. For nonsalmonids, we restricted observations to fish within a 2-m swath on each side of the observer. For salmonids, which were generally rare, large, and visible in the water column, we doubled the width of observation ( $4 \mathrm{~m}$ on each side).

The patchy distribution of fishes among these transects precluded analyses with standard parametric ANOVA, because the nonnormal distributions and unequal variances could not be remedied through data transformations. Consequently, we tested the effects of substrate type and depth with two-way ANOVA and multiple-range tests (when appropriate), using rank-transformed fish density data (Conover and Iman 1981). This technique improves the power of two-way analyses of main effects (i.e., depth and substrate type) over conventional nonparametric tests, but does not allow evaluation of interaction terms (Hora and Conover 1984; Thompson 1991).

\section{Effects of Shore-Zone Structures on Fish Density}

We examined the effects of shore-zone structures on fish density by means of a series of paired comparisons between fish densities associated with structures and densities in adjacent areas with a similar underlying substrate, but without structures. Our observations in Lake Tahoe indicated that minnows stayed within $10 \mathrm{~m}$ of complex rocky cover throughout the day and night (Beauchamp et al. 1991). Therefore, a spacing of $20-50 \mathrm{~m}$ between paired structure and no-structure areas was judged sufficient to detect any effect (attraction or repulsion relative to the adjacent no-structure site) that structures had on fish. Piers in Lake Tahoe consist of $20-30-\mathrm{cm}$-diameter steel or wood pilings, sunk into the substrate at approximately $5-\mathrm{m}$ intervals, with a solid deck on top. Piers provide simple submerged structures, which lack habitat complexity, and have a shadow zone. In contrast, cribs consist of a framework of timbers, filled with boulders and cobbles, which provides habitat complexity in three dimensions. The low lake level left many other structures dry or in extremely shallow water. Consequently we restricted our survey to structures that were flooded to a depth of at least $1-2 \mathrm{~m}$ at the lakeward end. Dimensions of the pier transects matched the length and width of the pier, plus the shadow zone formed by the deck of the pier. At cribs, we counted all fish visible along the face of the crib and within $2 \mathrm{~m}$ of the structure. It is probable that fish densities around the cribs were underestimated because fish hiding in the interstices of the cribs were not always detected. The mean dimensions of the piers were $23.0 \mathrm{~m}$ long and $2.2 \mathrm{~m}$ wide; the cribs averaged $25.0 \mathrm{~m}$ long and $5.2 \mathrm{~m}$ wide. We used the same 
length and width as that used on the associated structure for surveys of each paired no-structure area. In 1988 and 1989, we did daytime paired fish density comparisons for 70 of the 610 piers and 31 of the 84 cribs in the lake; these represented virtually all of the structures that satisfied our depth criterion. Under normal lake levels, cribs would be flooded to a deeper extent, but should not otherwise differ in their effects on fish. Piers might provide more cover to fish at higher lake levels because of the proximity of the deck and its shade zone to the surface of the water (e.g., Helfman 1981a). As a result, our study might have underestimated the potentially beneficial effects of cover provided by piers. In June and August 1990, we compared daytime fish counts from 22 paired pierno-pier transect and 6 crib-no-crib transects to nocturnal counts (using diving lights) in those same habitats.

\section{Results}

\section{Availability of Littoral Substrate Types}

The composition of substrates varied significantly between the dry, exposed shoreline, the nearshore littoral zone, and the deeper $(8-18 \mathrm{~m})$ offshore littoral zone (Kruskal-Wallis $P<0.0001$ for each substrate type; Figure 2). Gravel and large boulders were most common in the dry, exposed shoreline that extended two vertical meters above the current lake level. The intermediate sizes of rocky substrates $(12 \%$ cobbles and $11 \%$ small boulders) were most abundant in the submerged nearshore littoral zone. Sand was most prevalent in the offshore littoral zone and constituted over $80 \%$ of the littoral substrate below the $8-\mathrm{m}$ isobath (Figure 2).

Examination of the hypsographic curve for Lake Tahoe (C. Goldman, University of California, Davis, unpublished data) indicated that $6 \%\left(31.8 \mathrm{~km}^{2}\right)$ of the lake bottom was shallower than $10 \mathrm{~m}$ at mean lake level $(1,898.3 \mathrm{~m}$ above sea level), but the 1987-1992 drought reduced the lake level by $2 \mathrm{~m}$-to its lowest level in recorded history $(1,896.3$ $\mathrm{m}$ above sea level). This reduced the submerged area of the nearshore littoral zone, now $0-8 \mathrm{~m}$ deep, by approximately $79 \%\left(25.0 \mathrm{~km}^{2}\right)$. Cobbles and boulders constituted $62 \%$ of the substrate in the dry, exposed zone, but represented only $11 \%$ of the substrate in the offshore littoral zone (8-18 $\mathrm{m})$. The lowered lake levels reduced complex rocky habitat in the $0-10 \mathrm{~m}$ wetted zone by $20 \%$.

Because substrate composition varied significantly between areas of the lake (Kruskal-Wallis

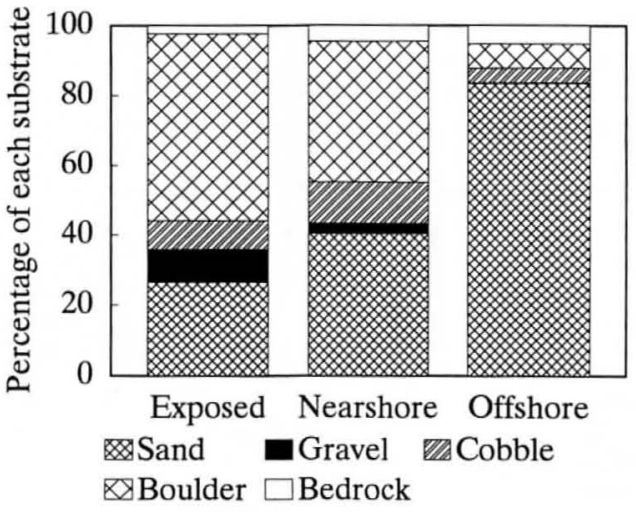

Figure 2.-Percentage composition of Lake Tahoe substrates in the shoreline zone exposed by drought, the submerged nearshore littoral zone ( $\leq 8 \mathrm{~m}$ deep), and the offshore littoral zone (8-18 $\mathrm{m}$ deep).

$P<0.00010$ ), the amount of rocky habitat loss also differed between areas. The proportion of complex rocky habitat was significantly lower in the nearshore littoral zone than in the dry, exposed zone in all but area 2 (Student-Newman-Keuls multiple-range test, $P<0.05$; Figure $3 \mathrm{~A}$, B). At the present lake level, sand composed the majority of the nearshore littoral substrate in the southern portion of the lake (area 5), whereas most of the submerged gravel was concentrated along the western side of the lake in area 2 (Figure $3 b$ ). Sand and silt were the predominant substrates below the $8-\mathrm{m}$ isobath in all areas of the lake (Figure 3c).

\section{Effects of Substrate and Depth on Fish Density}

The highest densities of littoral-zone fishes were found near boulder and cobble-boulder substrates. Two-way analysis of variance on the ranktransformed fish densities of each species indicated that only adult Lahontan redsides (depth effect: $P<0.005$; substrate effect: $P<0.01$ ) and tui chubs (depth effect: $P<0.002$; substrate effect: $P<0.001$ ) differed significantly by both depth and substrate. The highest densities of adult Lahontan redsides were associated with boulders at $1-10-\mathrm{m}$ depths and with cobble-boulder substrates at $3-10 \mathrm{~m}$; tui chubs concentrated in a much narrower range of habitats, having their highest densities in association with boulders at 3-10-m depths (Figure 4). The densities of juvenile Lahontan redsides $(P<$ $0.001)$, adult speckled dace $(P<0.02)$, Piute sculpin $(P<0.04)$, and rainbow trout $(P<0.001)$ differed significantly among substrate types, but not by depth. Peak daytime densities of juvenile 
A. Dry, exposed shoreline

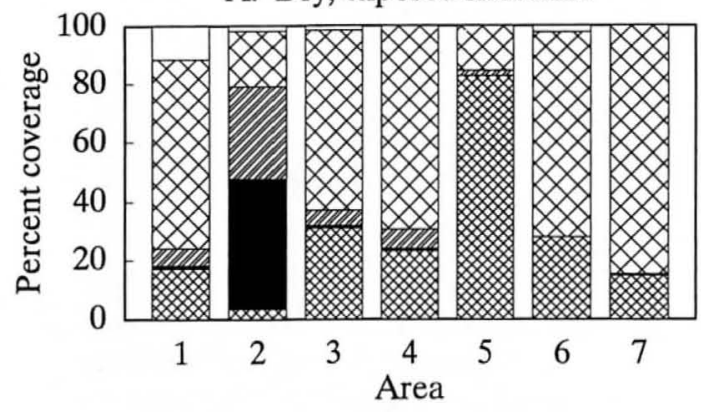

B. Nearshore

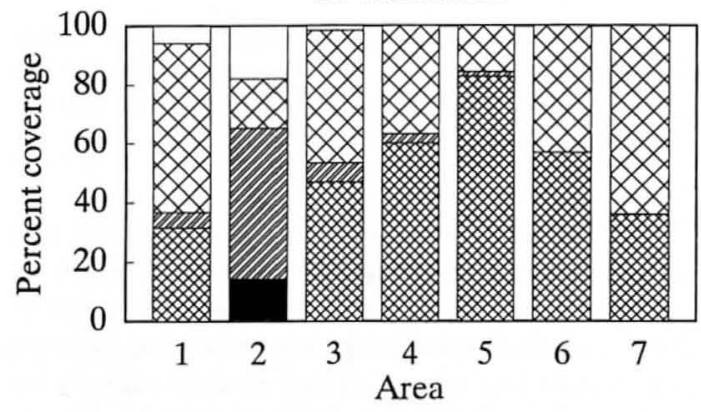

C. Offshore

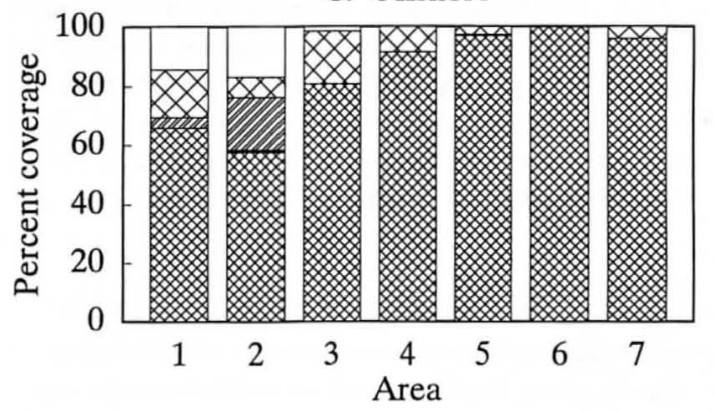

Sand Gravel Cobble 叉Boulder $\square$ Bedrock

FIGURE 3.-Substrate compositions in the seven sampling areas (Figure 1) of Lake Tahoe for: (A) the dry, exposed shoreline, (B) the nearshore littoral zone $(<8$ $\mathrm{m}$ deep), and (C) the offshore littoral zone (8-18 $\mathrm{m}$ deep).

Lahontan redsides were an order of magnitude lower than for the adults and were concentrated around boulders at 1-3-m depths; speckled dace were less abundant and were found primarily in rocky habitat; and adult rainbow trout densities were low and variable, but were generally highest around boulders and deep cobble-boulder habitats (Figure 4).
Effects of Shoreline Structures on Fish Densities Cribs were the only shoreline structures showing a significant effect on fish densities. The daytime density of individual fish species did not differ between the paired pier-no-pier transects (Wilcoxon signed-rank test, $P>0.25, N=91$ ). Fish densities associated with cribs, however, were many times higher than in the paired no-crib areas (Fig. ure $5 \mathrm{~A}$ ). Both daytime and nighttime densities of Lahontan redsides, tui chubs, juvenile Tahoe suckers, and speckled dace were significantly high. er around cribs than in the no-crib, pier, and nopier ares (Student-Newman-Keuls multiple-range test on rank-transformed fish densities; $P<0.05$; Figure 5A, B). The densities of other species were not different between the crib and no-crib areas $(P$ $>0.25, N=22$ ). The observed fish densities were significantly higher at night than during the day for the pier, no-pier, and no-crib transects $(P<$ $0.01)$, but not for the crib transects $(P>0.10$; Figure 5A, B).

We also examined the paired structure-nostructure comparisons of fish densities separately for each type of substrate because the previous analyses showed the importance of complex rocky substrates. For the pier-no-pier comparisons Lahontan redside densities were not significantly different within any category of substrate (for sandcobble: $P=0.11 ; P>0.3$ for comparisons over all other substrates; Wilcoxon signed-rank test). For the crib-no-crib comparisons, Lahontan redside densities were significantly higher around cribs over cobble substrate $(P<0.02)$, and nearly significant differences $(P<0.07)$ were found over cobble-boulder substrates.

\section{Discussion}

Habitat characteristics and depth had a marked effect on fish densities in the littoral zone of Lake Tahoe. In most cases, fish chose complex habitats with interstices (Figure 4). The affinity for complex habitats by littoral fishes is well documented for lakes and ponds with extensive macrophyte beds, but only a limited amount of work has been done in rocky substrates (Tabor and Wurtsbaugh 1991). It has most often been suggested that complex habitats serve as refuges from predation (e.g., Mittlebach 1981, 1984; Savino and Stein 1982; Werner et al. 1983a; Gotceitas and Colgan 1987; Johnson et al. 1988; Lynch and Johnson 1989) or as profitable foraging areas (Mittlebach 1981, 1984; Werner et al. 1983b). In most of these studies, the larger fishes (>100 mm standard length) were in- 

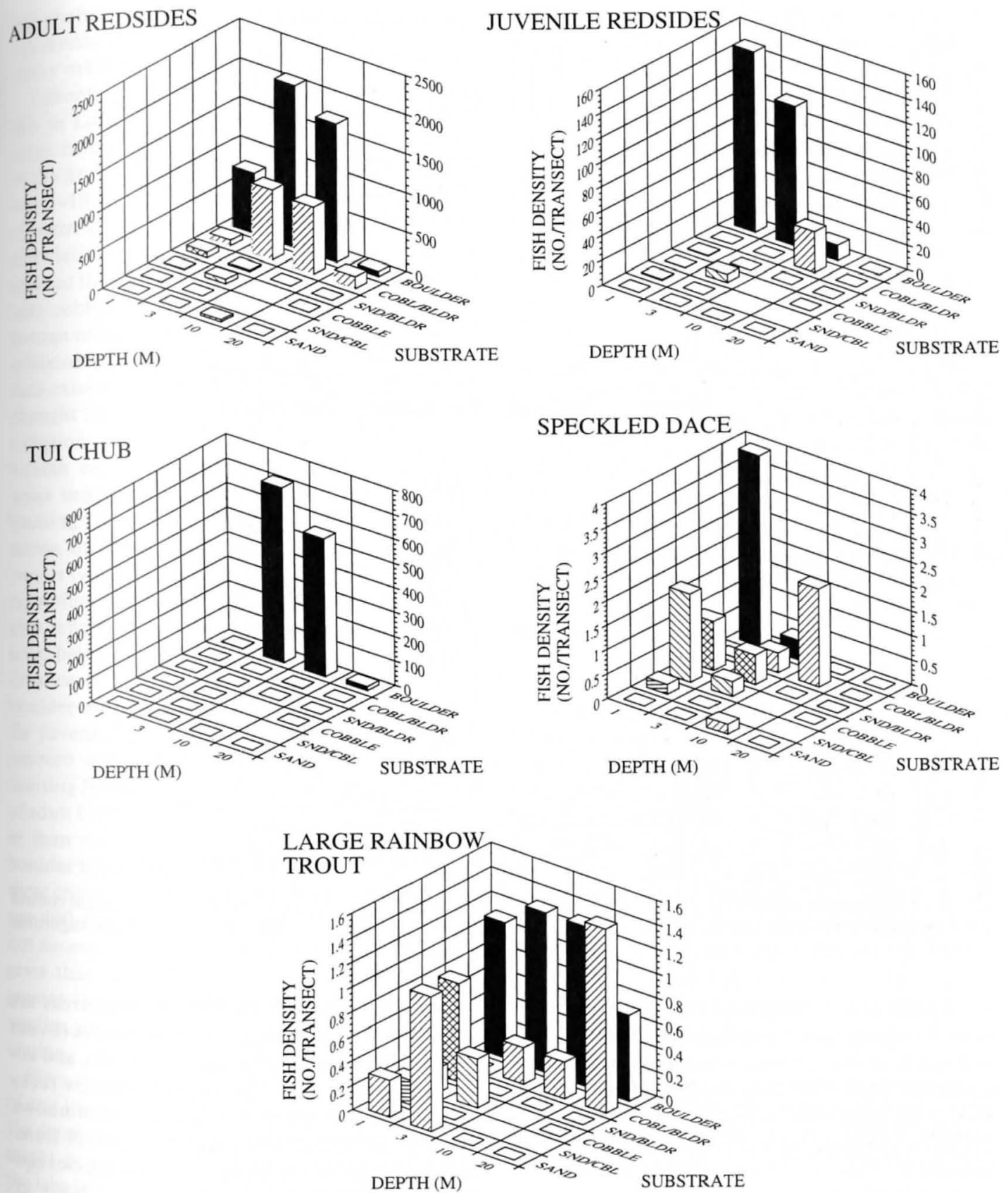

FIGURE 4.-Fish densities (number $/ 400 \mathrm{~m}^{2}$ ) related to depth and substrate for adult and juvenile Lahontan redsides, adult tui chubs, Lahontan speckled dace, and adult rainbow trout. Note that graph density scales differ.

vulnerable to piscivorous fishes and foraged among habitat types according to whichever was most profitable, whereas the smaller, more vulnerable fishes remained in or near the complex habitat. In Lake Tahoe, even the largest littoral minnows (130 $\mathrm{mm}$ total length) were vulnerable to predation by birds and trout, so rocky habitat is presumably important as a refuge from predation. We also noted that larger taxa, such as adult Tahoe suckers, or cryptic species, such as Piute sculpin, were more often observed over sand substrates, which suggests that the more vulnerable species were utiliz- 

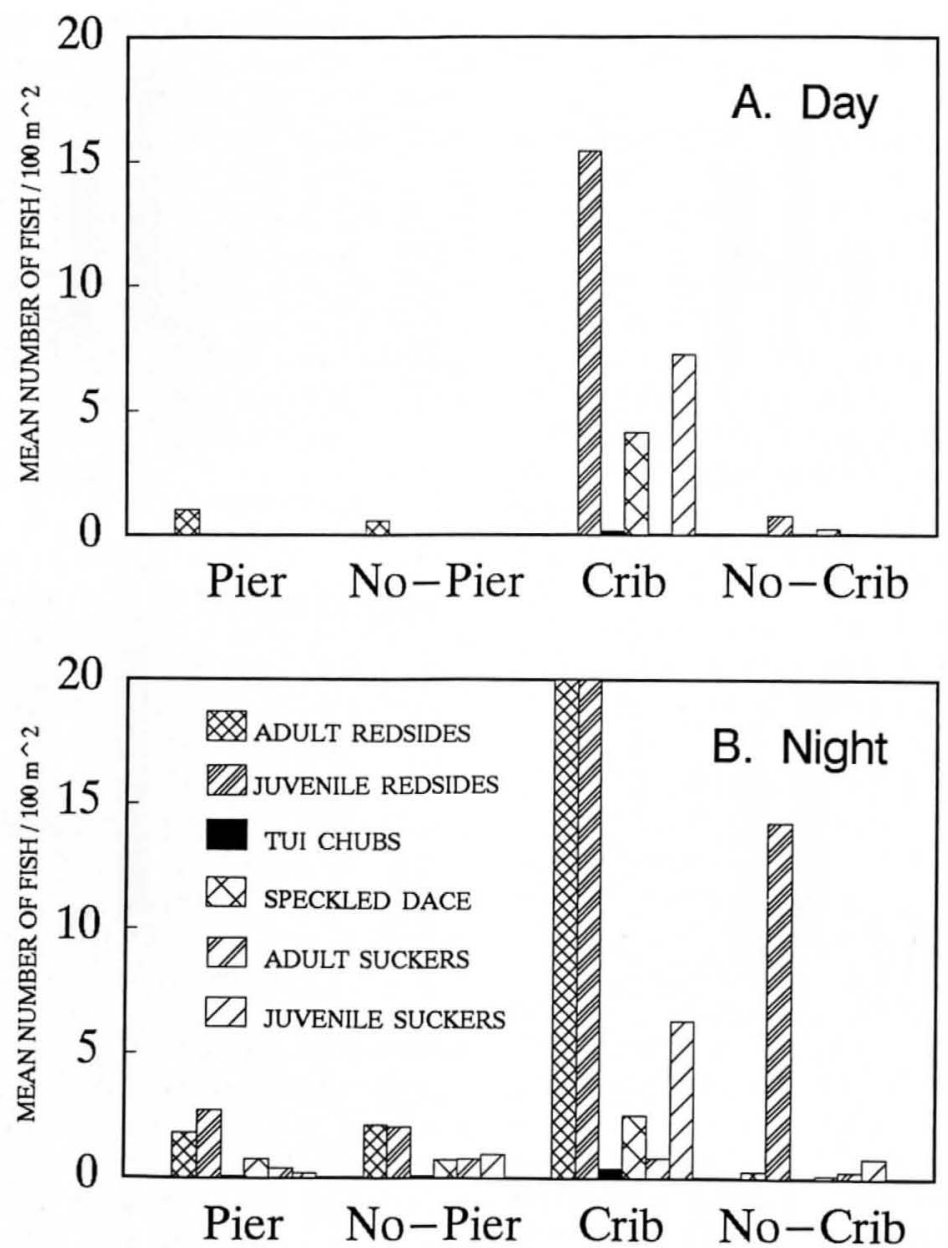

FIGURE 5.-Density (number $/ 100 \mathrm{~m}^{2}$ ) of fishes near pile piers (pier), rock-crib piers (crib), and in adjacent control areas (no-pier or no-crib) (A) during the day and (B) at night. Adult and juvenile Lahontan redside nighttime densities around cribs reached $48 / 100 \mathrm{~m}^{2}$ and $184 / 100 \mathrm{~m}^{2}$, respectively.

ing the complex substrates for cover. We should note, however, that the densities of Piute sculpin and speckled dace, both cryptic species, were undoubtedly biased because we did not attempt to survey the interstices of rocks or other cover. For example, juvenile Piute sculpin were sometimes found accidentally under tiny pieces of debris on sandy substrate.

At normal water levels, in large lakes lacking macrophytes, the very shallow littoral zone normally provides the most complex habitat because wave action sweeps away fine sediments and deposits them in deeper water. Consequently, a lowering of the lake level decreases the amount of complex habitat available to fish. In Lake Tahoe the drought-induced drawdown has reduced the amount of gravel substrate by $65 \%$, and cobble and boulder substrate by $20 \%$. Gravel areas are important for spawning Lahontan redsides (Evans 1969), Lahontan speckled dace, tui chubs, and kokanee (Cordone et al. 1971), and complex rocky habitat provides cover for all postlarval minnows. Whether the reduction in available gravel translates into reduced recruitment of these species cannot be ascertained from the existing data; however, a newly implemented population monitoring program (involving monthly minnow trapping depth profiles, hydroacoustic surveys of kokanees and tui chubs, and mark-recapture of lake trout) should provide information for future assessments of these game and nongame species. It is also important to note that, because substrates are unevenly distributed among areas of Lake Tahoe (Figure 3), lake drawdown may have minimal effects on hab- 
itat characteristics in some areas, but severe consequences elsewhere. This would also be true for many other lakes.

Lahontan redsides, the predominant nearshore fish in Lake Tahoe, were closely associated with large, complex rocky substrates in the upper $10 \mathrm{~m}$ of the littoral zone. The modal depth of the adults was 3-10 m, whereas juveniles resided in shallower waters, primarily at 1-3 m. Given this close association with shallow, rocky habitat, we examined the possibility that reductions in the available cobble-boulder habitat might limit the Lahontan redside population. Because this study was initiated during drought conditions, no baseline data exist to compare current fish densities to predrought conditions. However, the frequency distribution of the counts of juvenile and adult Lahontan redsides in cobble-boulder and boulder areas might suggest whether summer habitat is limiting. Zero counts could indicate underutilization of the existing habitat. Consistently high counts (with no zero counts) can only suggest the possibility of habitat limitation, because they might also reflect exploitation of the resource at some level below carrying capacity. The large preponderance of zero counts $(73 \%$ of all transects in boulder and cobble-boulder transects at 1-3 m) for juvenile Lahontan redsides suggests that the amount of available summer habitat was not a limiting factor to the juvenile population. Counts of adult Lahontan redsides were consistently greater than one per transect in cobble-boulder and boulder habitats at depths of 3-10 m, and $74 \%$ of these counts ranged between 100 and 10,000 adults per $400-\mathrm{m}^{2}$ transect. Although this analysis does not necessarily indicate resource limitation, it suggests that the potential for habitat limitation is greater for adult Lahontan redsides than for juveniles, given the current age structure of the population.

Piers had no significant effect on the densities of any littoral fishes, whereas cribs enhanced both the density and diversity of fishes. However, piers might positively influence fish abundance when the lake level is higher; Helfman (1981a) has shown that some species utilize shaded areas under docks as cover. During our observations most pier walkways were $2-3 \mathrm{~m}$ above the water surface, and thus provided little, if any shade.

In contrast, the vertical relief and interstitial spaces of the cribs provided both cover (e.g., Johnson et al. 1988; Lynch and Johnson 1989) and a greater attachment area for food organisms (Pardue 1973). In lake areas dominated by smaller, simpler substrates, cribs might provide the structural complexity necessary to attract minnows. These structures clearly provided cover for the small fish, as they would quickly disappear into the interstitial spaces of the crib when approached by divers. Other structures, such as solid bulkheads, that provide no interstitial spaces might be quite detrimental because they reduce the availability of the very shallow water (depth $<20 \mathrm{~cm}$ ) used by larval fish in Lake Tahoe (Miller 1951; authors' observations). Fortunately, such structures are rare in the lake.

Both the density and species composition of fishes associated with piers, cribs, and the control areas changed between day and night. Total fish densities in the littoral zone increased approximately 10 -fold at night relative to daytime densities. Most littoral fishes in Lake Tahoe were less associated with cover at night, regardless of whether they were nocturnally active (e.g., Helfman $1981 \mathrm{~b}$ ); this pattern has also been observed in cyprinids by Cerri (1983) under experimental conditions, and by Hall et al. (1979), Helfman (1981b), and Tabor and Wurtsbaugh (1991) for natural lake populations. This phenomenon illustrates the importance of diel changes in fish distribution and behavior in any examination of habitat use and community structure.

While the importance of habitat has been extensively studied in stream systems, fish ecologists in western North America have given little attention to the importance of the littoral zone as fish habitat. Since littoral fishes and crayfish are the primary prey for rainbow and brown trout throughout the year, and for lake trout seasonally, the productivity of sport fish populations is closely linked to the continued availability of nearshore fishes and invertebrates. We have shown that the littoral-zone habitat is quite important in Lake Tahoe and that anthropogenic modifications such as cribs can influence localized fish densities. However, the influence of some shore-zone structures (e.g., piers) on fish density may be minimal. We should caution that our study focused strictly on fish density. Although fish density is important, lake managers must also consider other factors, such as aesthetics and restrictions in use, when deciding whether piers or other shoreline modifications should be allowed in a system.

\section{Acknowledgments}

We thank the California Department of Fish and Game, the Nevada Department of Wildlife, and the Tahoe Regional Planning Agency for their 
coordinated financial and logistical support. Jeff Janik, Mark Vinson, Brant Allen, Phaedra Budy, and Bob Richards assisted us in the field. John Reuter and Charles Goldman provided advice and facilities support. Discussions with Hiram $\mathrm{Li}$ and Susan Durham helped with the design of the study.

\section{References}

Baker, P. R. 1967. Distribution, size composition, and relative abundance of the Lahontan speckled dace, Rhynichthys osculus robustus (Rutter), in Lake Tahoe. California Fish and Game 53:165-173.

Beauchamp, D. A., B. C. Allen, R. C. Richards, W. A. Wurtsbaugh, and C. R. Goldman. 1992. Lake trout spawning in Lake Tahoe: egg incubation in deepwater macrophytes. North American Journal of Fisheries Management 12:442-449.

Beauchamp, D., W. Wurtsbaugh, B. Allen, P. Budy, R. Richards, and J. Reuter. 1991. Lake Tahoe fish community structure investigation: phase III report. University of California, Institute of Ecology Publication 38, Davis.

Cerri, R. D. 1983. The effects of light intensity on predator and prey behavior in cyprinid fish: factors that influence prey risk. Animal Behaviour 31:736742 .

Conover, W. J., and R. L. Iman. 1981. Rank transformations as a bridge between parametric and nonparametric statistics. American Statistician 35:124129.

Cordone, A. J., S. J. Nicola, P. H. Baker, and T. C. Frantz. 1971. The kokanee salmon in Lake Tahoe. California Fish and Game 57:28-43.

Evans, D. H. 1969. Life history studies of the Lahontan redside, Richardsonius egregius, in Lake Tahoe. California Fish and Game 55:197-212.

Frantz, T. C., and A. J. Cordone. 1967. Observations on deepwater plants in Lake Tahoe, California and Nevada. Ecology 48:709-714.

Goldman, C. R. 1988. Primary productivity, nutrients, and transparency during the early onset of eutrophication in ultra-oligotrophic Lake Tahoe, California-Nevada. Limnology and Oceanography 33: 1321-1333.

Gotceitas, V., and P. Colgan. 1987. Selection between densities of artificial vegetation by young bluegills avoiding predation. Transactions of the American Fisheries Society 116:40-49.

Hall, D. J., and seven coauthors. 1979. Diel foraging behavior and prey selection in the golden shiner (Notemigonus crysoleucas). Journal of the Fisheries Research Board of Canada 36:1029-1039.

Hall, D. J., and E. E. Werner. 1977. Seasonal distribution and abundance of fishes in the littoral zone of a Michigan lake. Transactions of the American Fisheries Society 106:545-555.

Helfman, G. S. 1981a. The advantage to fish of hovering in shade. Copeia 1981:392-400.

Helfman, G.S. 1981b. Twilight activities and temporal structure in a freshwater fish community. Canadian Journal of Fisheries and Aquatic Sciences 38:1405. 1420.

Hopkirk, J. D., and R. J. Behnke. 1966. Additions to the known native fish fauna of Nevada. Copeia 1966 134-136.

Hora, S. C., and W. J. Conover. 1984. The $F$ statistic in the two-way layout with rank-score transformed data. Journal of the American Statistical Associa. tion 79:668-677.

Johnson, D. L., R. A. Beaumier, and W. E. Lynch. 1988. Selection of habitat structure interstice size by blue. gill and largemouth bass in ponds. Transactions of the American Fisheries Society 117:171-179.

Lane, E. W. 1947. Report of the subcommittee on sediment terminology. Transactions, American Geophysical Union 28:936-938.

Lynch, W. E., and D. L. Johnson. 1989. Influences of interstice size, shade, and predators on the use of artificial structures by bluegills. North American Journal of Fisheries Management 9:219-225.

Miller, R. G. 1951. The natural history of Lake Tahoe fishes. Doctoral dissertation. Stanford University, Palo Alto, California.

Mittlebach, G. G. 1981. Foraging efficiency and body size: a study of optimal diet and habitat use by bluegills. Ecology 62:1370-1386.

Mittlebach, G. G. 1984. Predation and resource partitioning in two sunfishes (Centrarchidae). Ecology 65:499-513.

Pardue, G. P. 1973. Production responses of the bluegill sunfish, Lepomis macrochirus Rafenisque, to added attachment surface for fish food organisms. Transactions of the American Fisheries Society 102: 622-626.

Savino, J. F., and R. A. Stein. 1982. Predator-prey interaction between largemouth bass and bluegills as influenced by simulated, submerged vegetation. Transactions of the American Fisheries Society 111: 255-266.

Tabor, R. A., and W. A. Wurtsbaugh. 1991. Predation risk and the importance of cover for juvenile rainbow trout in lentic systems. Transactions of the American Fisheries Society 120:728-738.

Thompson, G. L. 1991. A unified approach to rank tests for multivariate and repeated measures designs. Journal of the American Statistical Association 86:410-421.

Werner, E. E., J. F. Gilliam, D. J. Hall, and G. G. Mittlebach. 1983a. An experimental test of the effects of predation risk on habitat use in fish. Ecology 64 : 1540-1548.

Werner, E. E., G. G. Mittlebach, D. J. Hall, and J. F. Gilliam. 1983b. Experimental tests of optimal habitat use in fish: the role of relative habitat profitability. Ecology 64:1525-1539.

Wurtsbaugh, W. A., C. Brocksen, and C. R. Goldman. 1975. Food and distribution of underyearling brook and rainbow trout in Castle Lake, California. Transactions of the American Fisheries Society 104:8895. 